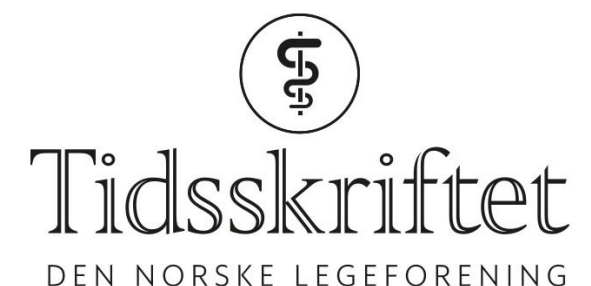

\title{
Dysregulering av proteinsyntese ved trisomi
}

FRA ANDRE TIDSSKRIFTER

HAAKON B. BENESTAD

Universitetet i Oslo

Dysregulering av proteinsyntese i mus og i humane celler fra personer med Downs syndrom gir redusert synapseplastisitet.

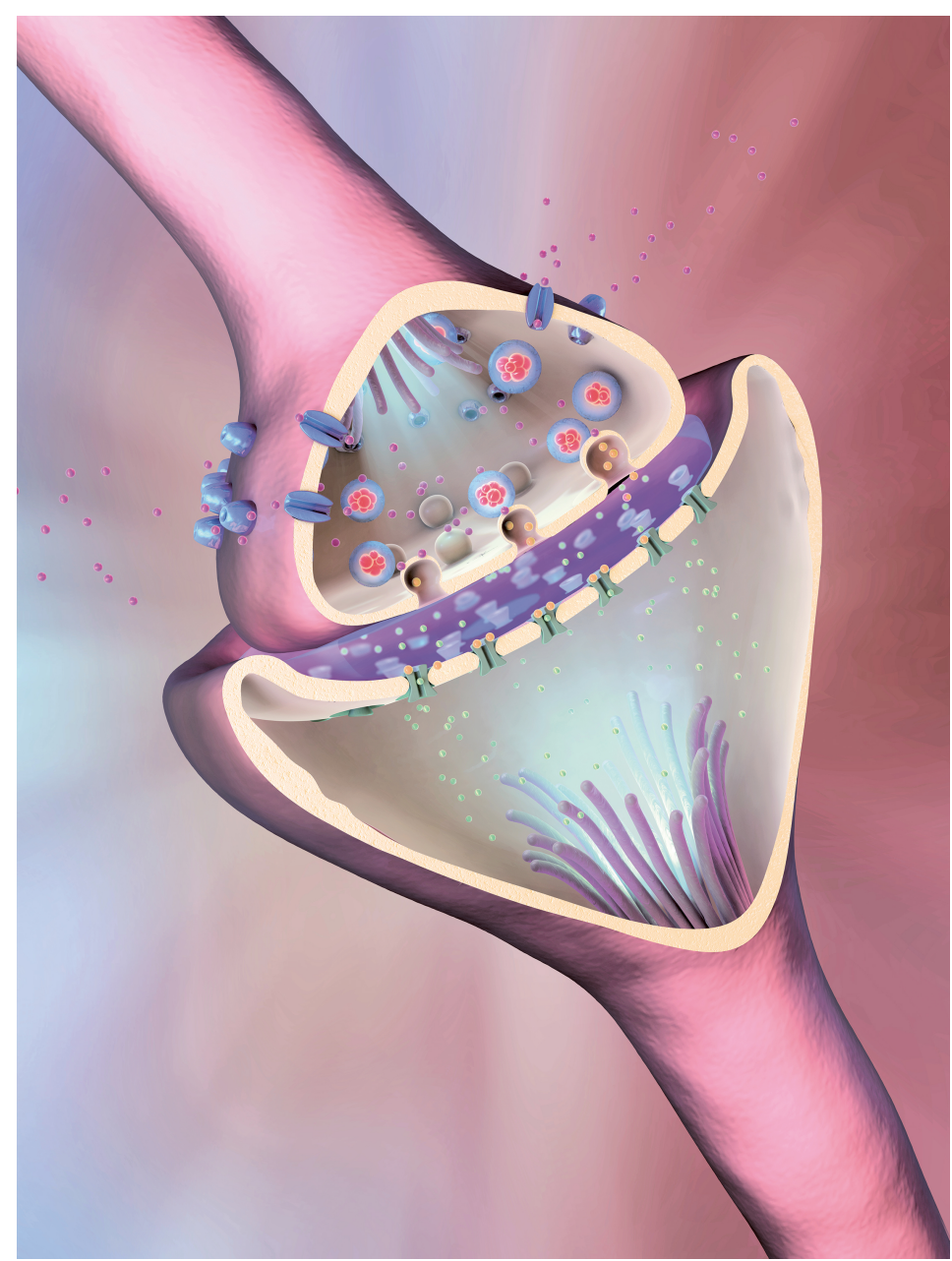

Illustrasjon: Science photo library/NTB Scanpix

Downs syndrom skyldes trisomi for kromosom 21 og kan ha mange patogenetiske mekanismer. En hypotese er at trisomien fører til en abnorm integrert stressrespons. Den 
normale stressresponsen forskyver balansen mellom syntese og degradering av proteiner og gir redusert proteinsyntese. Ved cellulært stress kan dette være gunstig inntil stresset er over, bl.a. for å unngå at nysyntetisert protein folder seg galt og blir cytotoksisk.

I en ny studie av mekanismen bak Downs syndrom er en initieringsfaktor (eIF2 $\alpha$ ) den patologisk affiserte komponenten i en skadelig nedsatt proteinsyntese (1). Fosforylering av signalproteiner brukes i cellene til å aktivere eller deaktivere signalene. I studien, en musemodell for Downs syndrom, fosforyleres elF2 $\alpha$-proteinet slik at proteinsyntesen reduseres mye mer enn i den gunstige stressresponsen. Proteinsyntesen ble så sterkt nedsatt at styrking av synapser - og dermed læring og hukommelse - ble redusert. Skadelig stressresponsaktivering ble også funnet i humane trisomale induserte pluripotente stamceller og i autopsihjerner fra personer med Downs syndrom.

Musene hadde defekt læring i flere hukommelsestester, men dette kunne korrigeres genetisk og farmakologisk. Mus med utslått gen for en komponent i stressresponsen (knockoutmus) fikk dessuten normalisert en rekke proteiner som er viktige for læring, hukommelse og synapseplastisitet.

- Denne studien viser overraskende sterke effekter av å normalisere den integrerte stressresponsen og dermed proteinsyntesen, sier Erik Dissen, som er professor ved Institutt for medisinske basalfag, Universitetet i Oslo.

- De fleste observasjonene ble gjort i en musemodell der trisomien er annerledes enn hos mennesket, slik at relevansen for Downs syndrom er usikker, påpeker han. Forstyrrelser i proteinhomøostasen ses også ved flere nevrologiske sykdommer. Noen medikamenter er under klinisk utprøvning ved slike sykdommer, men fordi proteinsyntesen er sentral $i$ alle kroppens celler, kan man frykte alvorlige bivirkninger ved langtidsbehandling med slike midler. Blokkeringen av proteinsyntesen kan dessuten være viktig i forsvaret mot virusinfeksjon, slik at reaktivering av latente virusinfeksjoner eller sårbarhet for nye infeksjoner kan tenkes. Det er derfor usikkert om farmakologisk intervensjon er en farbar eller ønskelig vei ved Downs syndrom, sier Dissen.

LITTERATUR:

1. Zhu PJ, Khatiwada S, Cui Y et al. Activation of the ISR mediates the behavioral and neurophysiological abnormalities in Down syndrome. Science 2019;366: 843-9. [PubMed][CrossRef]

Publisert: 22. mars 2020. Tidsskr Nor Legeforen. DOI: 10.4045/tidsskr.20.0025

(C) Tidsskrift for Den norske legeforening 2020. Lastet ned fra tidsskriftet.no 